\title{
Advances made by Belgrade's group in research of oscillatory reactions
}

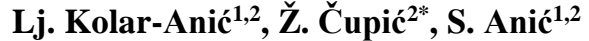 \\ ${ }^{1}$ University of Belgrade, Faculty of Physical Chemistry, Studentski trg 12-16, 11000 Belgrade \\ E-mail: lkolar@ffh.bg.ac.rs, boban@ffh.bg.ac.rs, \\ ${ }^{2}$ University of Belgrade, Institute of Chemistry, Technology and Metallurgy, Njegoševa 12, \\ 11000 Belgrade \\ e-mail: zcupic@ihtm.bg.ac.rs \\ *corresponding author
}

\begin{abstract}
Oscillatory dynamic states as one form of selforganization of nonlinear systems can be found in almost all sciences, like mechanics, physical chemistry or biomedicine. Although origin of these oscillations is different, computational challenges in modelling oscillatory phenomena remain similar in all fields. Since 1979 researchers from Belgrade's group perform systematic examinations of oscillatory reactions. As stability of steady states is the central point in modelling oscillatory reactions, in last 10 years they have adapted and improved powerful tool of the Stoichiometric Network Analysis for this goal. Moreover, bifurcations of few types were identified in several models of oscillatory reactions. Even very complex chaotic motions in phase space were characterized and quantified by several numerical techniques. Multiple time scale behaviour is found within the core of the complex dynamic behaviour of mixed-mode oscillations. Analytical applications were developed, too.
\end{abstract}

Keywords: Oscillatory reactions, Nonlinear dynamics, Stoichiometric Network Analysis, Numerical techniques for detection of periodic and aperiodic dynamic states, Analytical determination

\section{Introduction}

Some nonlinear reaction systems, when they are far from thermodynamic equilibrium, can be in an oscillatory dynamic state. These oscillations can be detected and monitored in time through the concentrations, temperature, electrochemical, spectroscopic or any other measurable properties of investigated reaction system. Such oscillatory reaction systems in which spontaneous periodic changes in the concentration of intermediates are observed were discovered accidentally. The detailed description of oscillatory reactions discovery can be found in several papers (Winfree 1984; Zhabotinskii 1991; Stávek et al. 2002; Epstein et al. 2006; Field et al. 1985; Kolar-Anić et al. 2017a; Kolar-Anić et al. 2017b; Kolar-Anić et al. 2017c; Kolar-Anić et al. 2017d), and books related to this subject (Nicolis et al. 1977; Epstein et al. 1998; Field et al. 1985). Investigations of such systems essentially changed our understanding of reaction systems in general and the way that contemporary scientists were thinking about them. It was found that these phenomena can be explained only by the main relations of 
nonlinear dynamics and basic statements of Nonequilibrium thermodynamics, two compatible sciences that investigate general phenomena of self-organization.

\subsection{Discovery of homogenous oscillatory reactions - The short overview}

The first study of experimentally controlled oscillatory dynamic states in a homogeneous reaction system was published in 1921 (Bray 1921). In this paper William C. Bray investigated the dual role of hydrogen peroxide during its decomposition in an acid solution of iodate ions.

$$
2 \mathrm{H}_{2} \mathrm{O}_{2} \underset{\mathrm{IO}_{3}^{-}, \mathrm{H}^{+}}{\stackrel{\mathrm{k}_{\mathrm{D}}}{\longrightarrow}} 2 \mathrm{H}_{2} \mathrm{O}+\mathrm{O}_{2}
$$

Since in the considered solution the global reaction (D) is the result of presence of two parallel processes where the reduction of iodate to iodine $(\mathrm{R})$ and the oxidation of iodine to iodate $(\mathrm{O})$ are performed,

$$
\begin{gathered}
2 \mathrm{IO}_{3}^{-}+2 \mathrm{H}^{+}+5 \mathrm{H}_{2} \mathrm{O}_{2} \stackrel{\mathrm{k}_{\mathrm{R}}}{\longrightarrow} \mathrm{I}_{2}+6 \mathrm{H}_{2} \mathrm{O}+5 \mathrm{O}_{2} \\
\mathrm{I}_{2}+5 \mathrm{H}_{2} \mathrm{O}_{2} \stackrel{\mathrm{k}_{\mathrm{O}}}{\longrightarrow} 2 \mathrm{IO}_{3}^{-}+2 \mathrm{H}^{+}+4 \mathrm{H}_{2} \mathrm{O},
\end{gathered}
$$

he concluded that the periodic domination of one of them can cause the oscillations of intermediate iodine species concentrations. Bray continued these investigations with his student Herman Liebhafsky (Bray et al. 1931; Liebhafsky 1931a; Liebhafsky 1931b; Liebhafsky 1932a; Liebhafsky 1932b; Liebhafsky et al. 1933; Liebhafsky 1934) and the aforementioned reaction was subsequently named the Bray-Liebhafsky (BL) oscillatory reaction.

Around 1950, Boris Pavlovich Belousov discovered independently the second homogeneous oscillatory reaction. (Field et al. 1985) He observed similar dynamic behaviour in a solution of citric acid, bromate and ceric ions $\left(\mathrm{Ce}^{4+}\right)$, where the yellow solution periodically cleared and became yellow again. However, he had serious troubles to publish these results. His attempt to publish them in 1951 did not succeed, since general opinion at that time was that this kind of dynamic behaviour is not in accordance with the second law of thermodynamics. After several years, in 1958, he published his work in the Book of abstracts at the Conference of radiation biology. (Belousov 1958) Later, posthumously, his original manuscript from 1951 was published in Russian (Belousov 1981) and in English (Belousov 1985). Anatol M. Zhabotinskii, a graduate student in biophysics, continued Belousov's initial work during the 1960's. He replaced the citric acid by malonic acid (Zhabotinskii 1964) and created the chemical system in which various concentration oscillations have been observed. Moreover, he added the redox indicator ferroin, to enable visualisation of the oscillation through periodical colour changes from red to blue and gave rise to spatio-temporal waves in a thin layer. This reaction, named the Belousov-Zhabotinskii (BZ) oscillatory reaction, became a very popular model system and attracted the attention of many scientists working in the fields of Nonequilibrium thermodynamics and Nonlinear dynamics.

The first explanation showing that this kind of dynamic behaviour is possible in homogeneous isothermal reaction systems came from Ilya Prigogine ${ }^{1}$ who introduced the concept of nonequilibrium thermodynamics and clearly distinguished entropy production in closed and open systems. Thus, it was demonstrated that nonequilibrium stationary states are not equal to the equilibrium ones, and that selforganization phenomena under these conditions differ from one another. Finally, dissipative structures are introduced to distinguish

\footnotetext{
${ }^{1}$ Prof. Ilya Prigogine was the Nobel Prize winner for chemistry in 1977.
} 
nonequilibrium selforganization phenomena from the ones found in an equilibrium (Prigogine 1977; Nicolis et al. 1989; Nicolis 1995).

The basic theoretical foundations for modelling the homogeneous oscillatory processes originate from Alfred Lotka who already at that time (1910-1925) postulated the mathematical model appropriate to simulate oscillatory evolution in reaction and population systems (Lotka 1910; Lotka 1920a; Lotka 1920b; Lotka 1925). His investigations together with those performed by Vito Voltera (1926) to explain ecological problems, comprise the Lotka-Voltera model which is the preferred model for describing predator-pray interactions. This model also formed the basis for several famous models, such as Brussellator, (Lefever et al. 1988) Oregonator (Field et al. 1974) and autocatalator, (Gray et al. 1986; Scott 1987; Gray et al. 1990) which were proposed to explain self-organized phenomena obtained experimentally in several complex nonlinear reaction systems (Belousov 1958; Zhabotinskii 1964; Briggs et al. 1973). Although these models had an important role in explaining the existence of stable and unstable nonequilibrium stationary states in nonlinear reaction systems, as well as the possible selforganizing phenomena in these states, a straightforward correlation between reaction species and mathematical variables was not established for a long time. The main problem was in the fact that direct autocatalytic reactions, necessary in the model to simulate oscillatory dynamics, do not appear in real reaction systems. The first model where a direct autocatalytic step was successfully substituted by a realistic autocatalytic loop was proposed in 1987 by Guy Schmitz who was working on the modelling of the Bray-Liebhafsky oscillatory reaction (Schmitz 1987). Building on the original model proposed by Schmitz, a more powerful variant of the model was developed (Kolar-Anić et al. 1992; Kolar-Anić et al. 1995a) that could simulate complex dynamical structures such as mixed-mode oscillations, period doubling and deterministic chaos (Kolar-Anić et al. 2004a; Kolar-Anić et al. 2004b; Ivanović et al. 2008; Ivanović et al. 2009; Kolar-Anić et al. 2010; Ivanović et al. 2011; Čupić et al. 2013). Thus, the connection between experimental and theoretical investigations was established and proved by numerical investigations.

\subsection{The investigations of Belgrade's group - historical background}

Since 1979 the Belgrade’s group emerged with systematic examinations of oscillatory reactions. The first of our results were related to the phenomenological studies of their dynamic behaviours and reaction kinetics (Anić et al. 1985; Anić et al. 1986a; Anić et al. 1986b; Anić et al. 1987; Anić et al. 1988; Anić et al. 1989a; Anić et al. 1989b; Anić et al. 1991; Anić et al. 1996; Anić. 1997a; Anić et al. 1997b; Anić et al. 1998; Anić et al. 2007; Anić et al. 2009; Blagojević 2000; Blagojević et al. 2008; Blagojević et al. 2009; Ćirić et al. 2000; Milenković et al. 2012; Radenković 1997; Stanisavljev et al. 1995; Stanisavljev 1997; Stanisavljev et al. 1998a; Stanisavljev et al. 1998b; Stanisavljev et al. 2002; Stanisavljev et al. 2011; Vukojević et al. 2000; Vukojević et al. 2002). Furthermore, various methods were developed for formal kinetics of homogenous oscillatory process (Anić et al. 1986a; Anić et al. 1987; Anić et al. 1988; Anić et al. 1996; Anić et al. 2007), as well as for the stability analysis of the postulated models (Kolar-Anić et al. 1995b; Schmitz et al. 2000). All investigations were used for different purposes, starting with the development of new analytical methods (Pejić et al. 2001; Pejić et al. 2003; Pejić et al. 2005; Pejić et al. 2006; Pejić et al. 2007a; Pejić et al. 2007b; Pejić et al. 2007c; Pejić et al. 2009; Pejić et al. 2011; Pejić et al. 2012; Pejić et al. 2013; Pejić et al. 2014a; Pejić et al. 2014b; Pejić et al. 2016; Vukojević et al. 1999; Vukojević et al. 2001) and the methods for determining the catalyst's activity (Čupić et al. 1995; Terlecki-Baričević et al. 1995; Pejić et al. 2001; Anić et al. 2009; Maksimović et al. 2011), as well as the influence of external fields on the evolution of the chemical oscillator (Stanisavljev et al. 2004; Stanisavljev et al. 2005; Stanisavljev et al. 2006; Stanisavljev et al. 2014) to modelling of biochemical processes (Jelić et al. 2008; Jelić et al. 2009; Čupić et al. 2016b; Čupić et al. in press; Kolar-Anić 2017d; 
Marković at. al 2011a; Čupić et al. in press; Marković et al. 2011b; Marković et al. 2016;) etc. (Anić et al. 1994; Čupić et al. 1996; Begović et al.2004).

Main contributions of the Belgrade group to the research of oscillatory reactions with emphasis on the results from the latest 10 years are given in the Section 2. The Belgrade group gave its contribution to both experimental investigation and theoretical description of several oscillatory systems including BL, BZ, Briggs-Rauscher (BR), hypothalamic-pituitary-adrenal (HPA), and others. In Subsection 2.1 the experimental investigations related to controlled generation of various dynamical states and bifurcations between them including precise quantification of their complexity using several methods, such as Power spectrum, Lyapunov exponents, Return maps, etc, are presented. Next, also important track of experimental investigation is given in Subsection 2.2. In fact, this part refers to the formal kinetic analysis of homogeneous oscillatory reactions using (the traditional way and) the methods specially developed for oscillatory reactions. Finally, the developed applications of oscillatory reaction systems in analytical procedures for determination of pharmaceutically active substances and their antioxidative activity are given in the Subsection 2.3. On the other side, the results of modelling the considered reaction systems are presented in the Subsection 2.4. For achieving best performances of the developed models, sophisticated mathematical apparatus of SNA was used and improved. Also, there is a brief review of the influences of microwave (MW) and radiofrequency (RF) fields on the BL reaction (Subsection 2.5). Instead of conclusions, our vision of future trends in the field is given in the Section 3.

\section{Contemporary research in Belgrade group}

From the beginning as well as in the last ten years, we analyze oscillatory dynamics of reaction systems, more precisely, dynamical states of chemical, physicochemical and biochemical reaction systems, both experimentally and theoretically using numerical method to correlate obtained results. Although our systems are different from mechanical oscillators, we also examine stability of the states, oscillatory regions, bifurcation points, periodic and aperiodic oscillations (deterministic chaos), the standard notions in Nonlinear dynamics. Necessary mathematical equipment is similar or even the same as the one applied in other scientific fields. Thus, the obtained deterministic chaos in reaction system must be analysed and proved by common methods for deterministic chaos.

\subsection{Controlled generation of various dynamic states}

Controlled generation of various dynamic states, from regular oscillatory to the chaotic ones, has been our main aim from the beginning. The experimental results stimulated theoretical investigations and vice versa (Fig.1). Thus, experimentally obtained mixed-mode and chaotic states influenced their modelling. When we found that our model of the BL reaction confirms the existence of the deterministic chaos in this system (Kolar-Anić et al. 2004a; Kolar-Anić et al. 2004b) the attention in our experimental investigation moved to even more complex oscillations (Schmitz et al. 2006). Consequently, the exotic dynamic states were generated under controlled conditions in the BL system (Pejić et al. 2011; Bubanja et al. 2016) and also in the BR reaction perturbed by phenol (Čupić et al. 2014). As a result, the possibility to generate and control the intermittent dynamics in the BL reaction (Fig. 2) is demonstrated for the first time, without addition of any perturbing substances. 


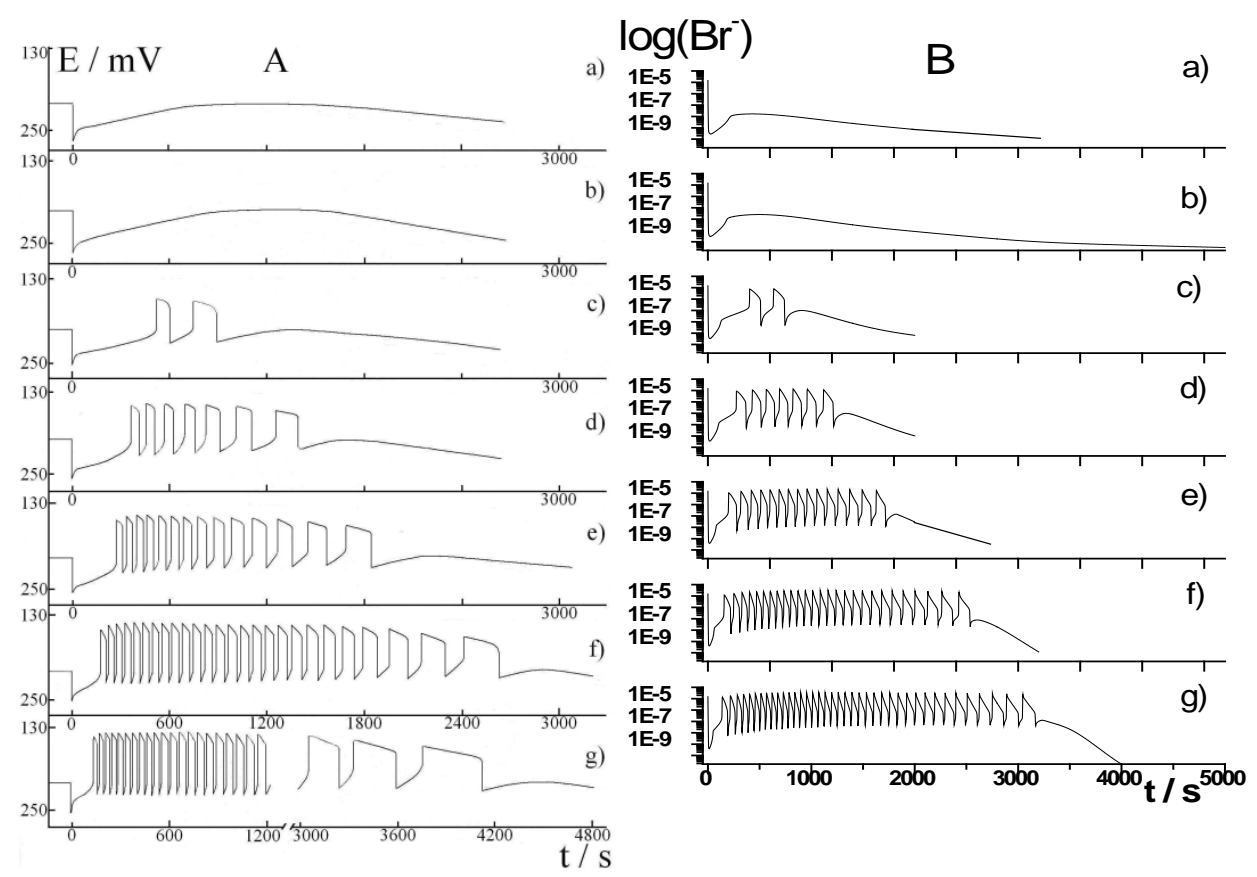

Fig. 1. Oscillograms in BZ system obtained experimentally A) and numerical simulation B) for the temperature $35^{\circ} \mathrm{C}$ and initial concentration of malonic acid $\left(\mathrm{mol} \mathrm{dm}^{-3}\right)$ : a) $8,00 \times 10^{-3}$; b) $9,00 \times 10^{-3}$; c) $1,20 \times 10^{-2}$; d) $1,60 \times 10^{-2}$; e) $2,20 \times 10^{-2}$; f) $3,20 \times 10^{-2}$; g) $4,30 \times 10^{-2}$;

Oscillograms obtained by numerical simulation are based on BG (1-12) model

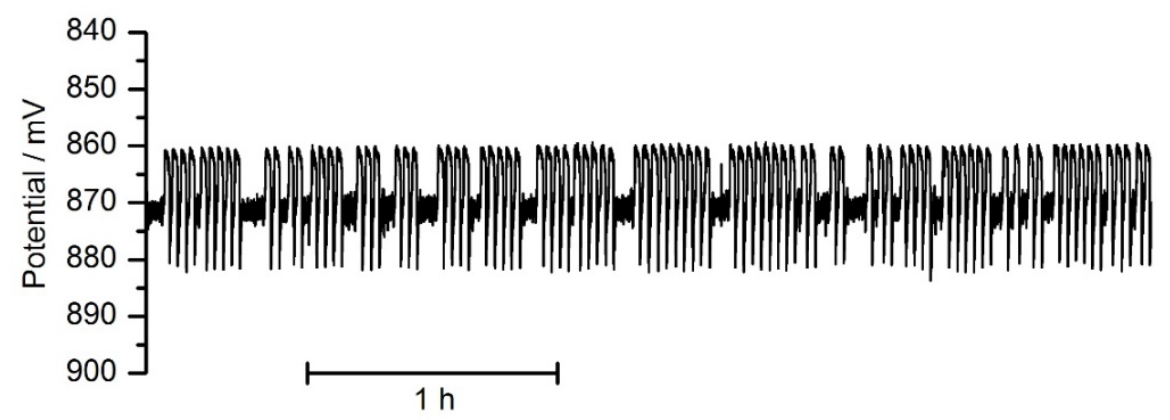

Fig. 2. Oscillogram (potential vs time) of the intermittent dynamic state obtained in BrayLiebhafsky oscillatory reaction generated in continuously fed stirred tank reactor (CSTR)

Methods for characterization of intermittencies were developed and deterministic nature of the phenomena is proved in both BL and BR system. In general, exotic dynamic states (Fig.3) were characterized by various mathematical techniques, starting from the Lyapunov exponents, Poincare sections, return maps, multifractal distributions, etc (Kolar-Anić al. 2006; Pejić et al. 2009; Čupić et al. 2014; Ivanovo et al. 2008; Ivanović et al. 2009; Ivanović et al. 2011; Čupić et al 2013; Blagojević et al. 2015; Bubanja et al. 2016; Čupić et al. 2016a). 


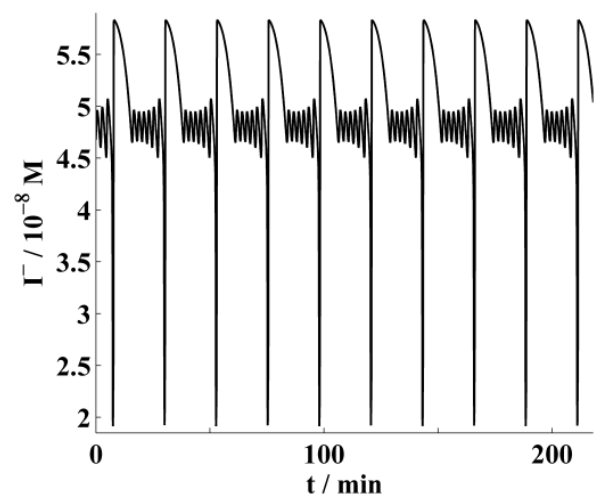

(a)

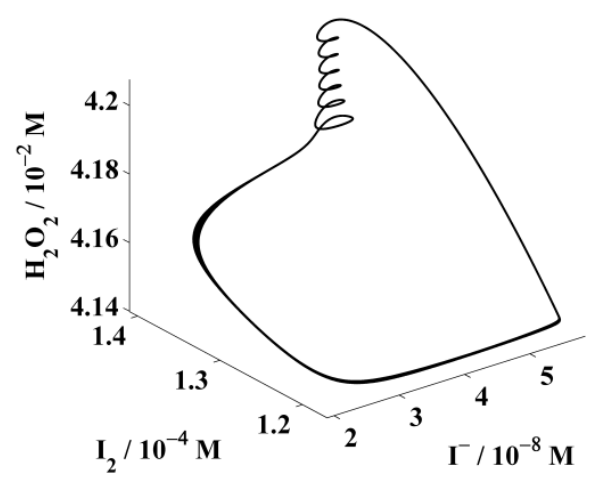

(b)

Fig. 3. Numerical simulations of the complex mixed mode oscillations in the BL reaction model. (a) Time series; (b) Phase space attractor

The dynamic states and kinetics of Belousov-Zhabotinsky reaction was also examined (Blagojević et al. 2008; Blagojević et al. 2009). We have examined the influence of temperature and malonic acid concentration on the dynamic states of the BZ system. Improved variant of the model was proposed and excellent agreement is achieved between the experiment and numerical simulations (Blagojević et al. 2011; Blagojević et al. 2013).

\subsection{Evaluation of kinetic parameters}

Almost all methods for evaluation of kinetic parameters of oscillatory reactions are developed on the BL reaction (Anić et al. 1986a; Anić 1987; Anić et al. 1988; Anić et al. 1989a; Anić et al. 1996a; Anić et al. 1996b; Anić 1997a; Anić et al. 1997b) and later applied to other ones (Blagojević et al. 2000; Blagojević et al. 2008; Blagojević et al. 2009). So, it was the case with the rate constants of overall process (D), as well as the reaction routes (O) and (R) and its corresponding apparent activation energies and also order and pseudo orders of overall reaction (D). The two competing routes (R) and (O) were clearly obtained both experimentally and theoretically by application of the same phenomenological methods on the experimentally obtained results as well as on the proposed models.

The BL reaction was also used as the reaction medium for the catalyst characterization (Anić et al. 2009; Maksimović et al. 2011). Cobalt ions on porous polymer support were used to perturb the kinetics of the BL system. Catalytic activity was then evaluated based on apparent activation energies. By calculating apparent activation energies of the reduction and oxidation processes in the BL reaction and their dependence on the mass of added catalyst, the oxidative catalytic activity of the tested catalyst activity was evaluated.

\subsection{Analytical procedures}

The oscillatory reactions with at least two reaction routes and very low concentrations of intermediate species are extremely sensitive on perturbations and therefore appropriate for analytical purposes. Using them, analyte pulse perturbation techniques (Fig. 4) were developed for determination of paracetamol, ascorbic acide, morphine, 6-monoacetylmorphyne, piroxicam, and also for uric acid in human urine (Pejić et al. 2006; Pejić et al. 2007a; Pejić et al. 2007b; Pejić et al. 2007c; Pejić et al. 2012; Pejić et al. 2014). 

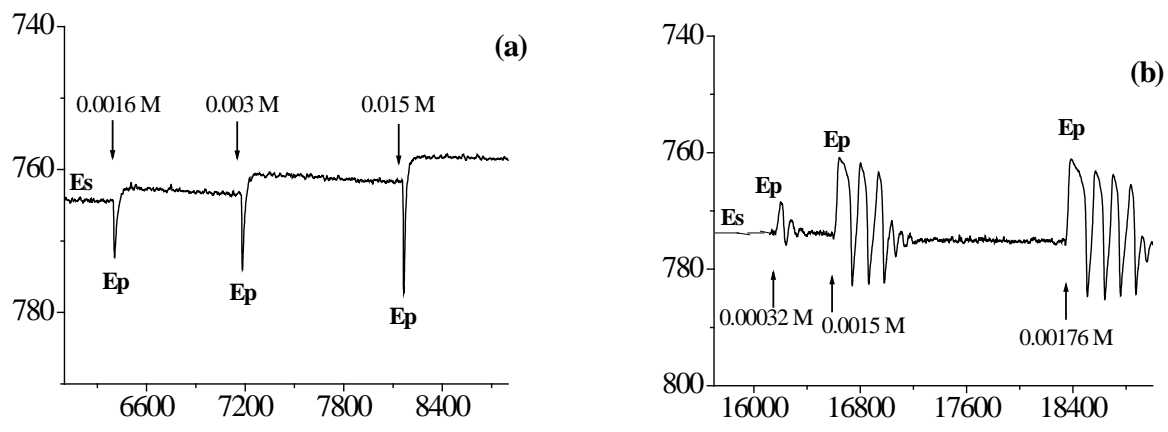

Fig. 4. Potentiometric responses of BL analyte matrix, which is originally in the stationary state, obtained after the pulse perturbation by various concentrations of vitamin B1 (a) and B2 (b). Arrows indicate the moment of perturbation

\subsection{Modeling}

For controlled generation of various dynamic states and prediction of dynamic states of the reaction system, the model of the process ought to be postulated. Modeling procedure is a serious task. It depends very much on the system under consideration. For this purpose, theory of the Stoichiometric Network Analysis was improved and used for identification of the instability regions in several models of the oscillatory reactions (Jelić et al. 2008; Schmitz et al. 2008; Jelić et al. 2009; Kolar-Anić et al. 2010; Cupić et al. 2011; Marković et al. 2011a; Maćešić et al. 2012; Maćešić et al. 2015a; Maćešić et al. 2015b; Maćešić et al. 2016; Čupić et al. 2016b; Čupić et al. 2016c). Here, as in the case of formal kinetics, the main steps in modelling procedure were developed on the BL reaction and then applied to the other systems. Thus, multiple time scale dynamics of the BL reaction model was identified as a source of the mixed-mode oscillations (Fig. 5) and tourbillion mechanism was recognized (Čupić et al. 2013). Complex bifurcations were also found in this model and confirmed by both numerical evidence and theoretical considerations (Stanković et al. 2013; Stanković et al. 2016). Details of the reaction mechanism were studied in the model of the BZ reaction (Fig. 1B) and complex oscillations were also discovered there (Blagojević et al. 2011; Blagojević et al. 2013 and Table $1)$. 


$$
\begin{aligned}
& \text { (BG1) } \mathrm{Br}^{-}+\mathrm{HOBr}+\mathrm{H}^{+} \rightarrow \mathrm{Br}_{2}+\mathrm{H}_{2} \mathrm{O} \\
& \text { (BG-1) } \quad \mathrm{Br}_{2}+\mathrm{H}_{2} \mathrm{O} \rightarrow \mathrm{Br}^{-}+\mathrm{HOBr}+\mathrm{H}^{+} \\
& \text {(BG2) } \quad \mathrm{HBrO}_{2}+\mathrm{Br}^{-}+\mathrm{H}^{+} \rightarrow \mathrm{Br}_{2} \mathrm{O}+\mathrm{H}_{2} \mathrm{O} \\
& \text { (BG3) } \quad \mathrm{Br}_{2} \mathrm{O}+\mathrm{H}_{2} \mathrm{O} \rightarrow 2 \mathrm{HOBr} \\
& \text { (BG-3) } \quad 2 \mathrm{HOBr} \rightarrow \mathrm{Br}_{2} \mathrm{O}+\mathrm{H}_{2} \mathrm{O} \\
& \text { (BG4) } \mathrm{Br}^{-}+\mathrm{BrO}_{3}^{-}+2 \mathrm{H}^{+} \rightarrow \mathrm{HOBr}+\mathrm{HBrO}_{2} \\
& \text { (BG5) } 2 \mathrm{HBrO}_{2} \rightarrow \mathrm{BrO}_{3}{ }^{-}+\mathrm{HOBr}+\mathrm{H}^{+} \\
& \text {(BG6) } \mathrm{BrO}_{3}^{-}+\mathrm{HBrO}_{2}+\mathrm{H}^{+} \rightarrow 2 \mathrm{BrO}_{2}{ }^{\bullet}+\mathrm{H}_{2} \mathrm{O} \\
& \text { (BG-6) } 2 \mathrm{BrO}_{2}{ }^{\bullet}+\mathrm{H}_{2} \mathrm{O} \rightarrow \mathrm{BrO}_{3}^{-}+\mathrm{HBrO}_{2}+\mathrm{H}^{+} \\
& \text {(BG7) } \mathrm{Ce}^{3+}+\mathrm{BrO}_{2}^{\bullet}+\mathrm{H}^{+} \rightarrow \mathrm{Ce}(\mathrm{IV})+\mathrm{HBrO}_{2} \\
& \text { (BG-7) } \mathrm{Ce}^{4+}+\mathrm{HBrO}_{2} \rightarrow \mathrm{Ce}^{3+}+\mathrm{BrO}_{2}^{\bullet}+\mathrm{H}^{+} \\
& \text {(BG8) } \quad \mathrm{MK}+\mathrm{Br}_{2} \rightarrow \mathrm{BrMK}+\mathrm{Br}^{-}+\mathrm{H}^{+} \\
& \text {(BG9) } \mathrm{MK}+\mathrm{Ce}^{4+} \rightarrow \mathrm{Ce}^{3+}+\mathrm{P}_{1}+\mathrm{H}^{+} \\
& \text {(BG10) } \mathrm{BrMK}+\mathrm{Ce}^{4+} \rightarrow \mathrm{Ce}^{3+}+\mathrm{Br}^{-}+\mathrm{P}_{2} \\
& \text { (BG11) } \mathrm{MK}+\mathrm{Br}_{2} \mathrm{O} \rightarrow \mathrm{BrMK}+\mathrm{HOBr} \\
& \left(\text { BG12) } \mathrm{Br}_{2} \text { (rast.) } \rightarrow \mathrm{Br}_{2}\right. \text { (g) }
\end{aligned}
$$

Table 1. Model BG(1-12) of the BZ reaction consisting of 12 reactions: BG1-BG12.

(Blagojević et al. 2008) Remark: P1 and P2 are the products 


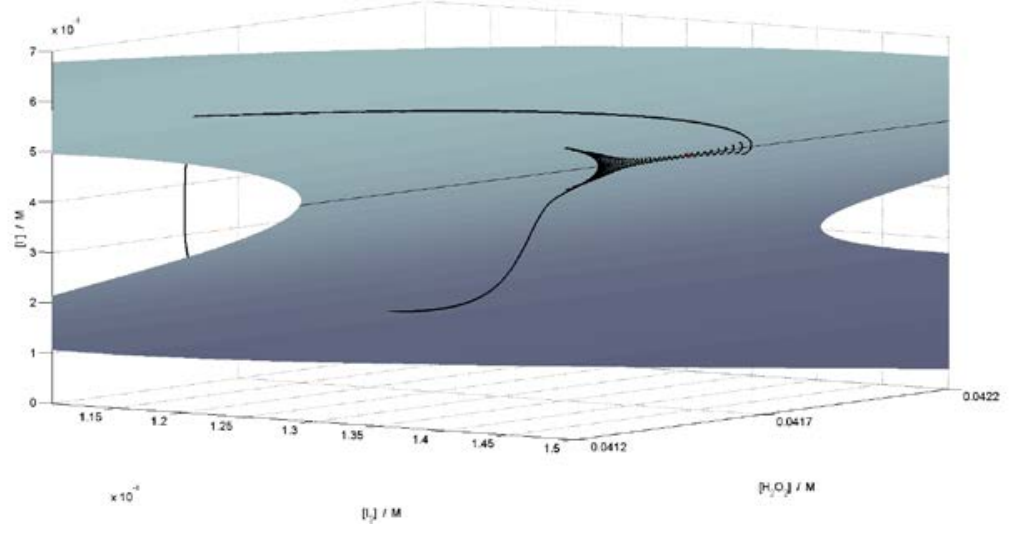

Fig. 5. Critical manifold of the BL reaction model and numerically simulated phase space trajectory over it. Fold line of the critical manifold is also given

Much of our work in the last decade was dedicated to the investigation of the HPA axis, and influences of several perturbing substances on its dynamics (Marković et al. 2011b; Marković et al. 2016; Čupić et al. 2016b; Čupić et al. in press). Due to inherent ultradian oscillations, our model of the HPA axis has a phase sensitive response on perturbations. This property was crucial for successful simulation of numerous effects which were previously unexplained, like different reaction on the same stress during night and day.

\subsection{Oscillatory reactions in external fields}

The researches of the influence of external fields were commenced in 2014 (Stanisavljev et al. 2004; Stanisavljev et al. 2005). This investigation persists until the present day. So, the influence of MW (2.45 GHz) and RF (30-120 MHz) electromagnetic radiation on the oscillatory reactions was examined at the constant bulk temperature (Stanisavljev et al. 2006; Stanisavljev et al. 2007; Stanisavljev et al. 2011; Stanisavljev et al. 2014). It was found that highly absorbed microwaves decrease the number of oscillations where as reaction dynamics is not affected by $\mathrm{RF}$ radiation.

\section{Perspectives}

Belgrade group is continually spreading its interests in the area of new oscillating reaction systems, new experimental and theoretical techniques, and it keeps producing new insights in the reaction mechanism underlying complex dynamical states. The new contributions to the understanding of the intermittent behaviour in the BL reaction can be expected. Further progress in modelling HPA axis under basal and stress conditions is also in front of us.

Acknowledgements This work was partially supported by the Ministry of Education, Science and Technological Development of the Republic of Serbia (Grants no. 172015 and 45001). We are grateful to our collaborators Nataša Pejić, Slavica Blagojević, Ana Ivanović-Šašić, Jelena Maksimović, Stevan Maćešić and Itana Nuša Bubanja for the help during the preparation of the manuscript. 
Извод

\title{
Доприноси Београдске групе изучавању осцилаторних реакција
}

\author{
Љ. Колар-Анић ${ }^{1,2}$, Ж. Чупић ${ }^{2 *}$, С. Анић ${ }^{1,2}$ \\ ${ }^{1}$ Универзитет у Београду, Факултет за физичку хемију, Студентски трг 12-16, 11000 \\ Београд \\ имејл: lkolar@ffh.bg.ac.rs, boban@ffh.bg.ac.rs, \\ ${ }^{2}$ Универзитет у Београду, Институт за хемију, технологију и металургију, Његошева 12 , \\ 11000 Београд \\ имејл: zcupic@ihtm.bg.ac.rs \\ * главни аутор
}

\section{Резиме}

Осцилаторна динамичка стања, као облик самоорганизације нелинеарних система, могу се наћи у готово свим наукама, као што су механика, физичка хемија или биомедицина. Иако је порекло ових осцилација различито, тешкоће у моделирању осцилаторних феномена су заједничке на свим пољима. Од 1979. године истраживачи Београдске групе систематски истражују осцилаторне реакције. Како је стабилност устаљених стања кључни проблем у моделирању осцилаторних реакција, у последњих 10 година они су за ту намену усвојили и унапредили моћну технику Анализе стехиометријских мрежа. Затим је идентификовано више типова бифуркација у неколико модела осцилаторних реакција. Чак су и веома сложена хаотична кретања у концентрационом фазном простору окарактерисана и квантификована различитим нумеричким техникама. Установљено је да извор осцилација мешаних модова и других уочених сложених облика динамике представљају процеси који се одигравају на различитим временским скалама. Такође су развијене и аналитичке примене осцилаторних реакција.

Кључне речи: осцилаторне реакције, нелинеарна динамика, Анализа стехиометријских мрежа, нумеричке технике за детекцију периодичних и апериодичних динамичких стања, аналитичка детерминација

\section{References}

Anić S, Mitić, D, Kolar-Anić Lj (1985). The Bray-Liebhafsky Reaction. I. Controlled Development of Oscillations, J. Serb. Chem. Soc., 50, 53-59, 505.

Anić S, Kolar-Anić Lj (1986a). Some New Details in the Kinetic Considerations of the Oscillatory Decomposition of Hydrogen Peroxide, Ber. Bunsenges. Phys. Chem., 90, 539542.

Anić S, Kolar-Anić Lj (1986b). The Oscillatory Decomposition of $\mathrm{H}_{2} \mathrm{O}_{2}$ Monitored by the Potentiometric Method with $\mathrm{Pt}$ and $\mathrm{Ag}^{+} / \mathrm{S}^{2-}$ Indicator Electrode, Ber. Bunsenges. Phys. Chem., 90, 1084-1086.

Anić S, Kolar-Anić Lj (1987). The Influence of Potassium Iodate on Hydrogen Peroxide Decomposition in Bray-Liebhfasky Reaction, Ber. Bunsenges. Phys. Chem., 91, 10101013. 
Anić S, Kolar-Anić Lj (1988). Kinetic Aspects of the Bray-Liebhafsky Oscillatory Reaction, $J$. Chem. Soc. Faraday Trans. I, 84, 3413-3421 and other references therein.

Anić S, Stanisavljev D, Krnajski Belovljev G, Kolar-Anić Lj (1989a). Examination of the Temperature Variations on the Bray-Liebhafsky Oscillatory Reaction, Ber. Bunsenges. Phys. Chem., 93, 488-491.

Anić S, Vukojević V, Radenković M, Kolar-Anić, Lj (1989b). New Approach to the Study of the Peroxide Kinetics of the Briggs-Raushcer Oscillatory Reaction, J. Serb. Chem. Soc., 54, 521-526.

Anić S, Kolar-Anić Lj, Stanisavljev D, Begović N, Mitić D (1991). Dilution Reinitiated Oscillations in the Bray-Liebhafsky System, React. Kinet. Catal. Lett., 43, 155-162.

Anić S, Veselinović D, Vukojević V, Radenković M (1994). Electrochemical Source of Alternating Current based on an Oscillating Reaction, J. Serb. Chem. Soc., 59, 457-461.

Anić S, Stanisavljev D (1996a). Bray-Liebhafsky Oscillatory Reaction. V. New Kinetic Data on Low-Acidity Reaction Systems, J. Serb. Chem. Soc., 61, 125-127.

Anić S, Kolar-Anić Lj (1996b). The Bray-Liebhafsky Reaction. VI. Kinetic in the Iodide Oscillations, J. Serb. Chem. Soc., 61, 887-891 and other references therein.

Anić S (1997a). Relation between the Number of Oscillations and the Activation Energy of an Oscillatory Process, J. Serb. Chem. Soc., 62, 65-69.

Anić S, Kolar-Anić Lj, Körös E (1997b). Methods to Determine Activation Energies for the Two Kinetic States of the Oscillatory Bray-Liebhafsky Reaction, React. Kinet. Catal. Lett., 61, 111-116.

Anić S, Stanisavljev D, Čupić Ž, Radenković M, Vukojević V, Kolar-Anić Lj (1998). The Selforganization Phenomena During Catalytic Decomposition of Hydrogen Peroxide, Science of Sintering, 30, 49-57 and other references therein.

Anić S, Kostić M, Ninić M, Blagojević S, Kolar-Anić Lj (2007). Activation Energies as the Validity Criterion of a Model for Complex Reactions that can be in Oscillatory States, Science of Sintering, 39, 77-83 and other references therein.

Anić S, Maksimović J, Lončarević D, Pejić N, Čupić ŽD (2009). Activity of Polymer Supported Cobalt Catalyst in the Bray-Liebhafsky Oscillator, Russian J. Phys. Chem. A, 83, 1468-1471.

Begović N, Marković Z, Anić S, Kolar-Anić Lj (2004). Computational Investigation of HIO and $\mathrm{HIO}_{2}$ Isomers, J. Phys. Chem. A, 108, 651-657.

Belousov BP (1958). A Periodic Reaction and Its Mechanism. Sbornik Referatov po Radiatsionni Medetsine, Moskow, SSSR.

Belousov BP (1981). A Periodic Reaction and Its Mechanism, in Grecova, M. T. (Ed.), USSR Academy of Sciences, Institute of Applied Physics, Gorky, pp 176-186;

Belousov BP (1985). A Periodic Reaction and Its Mechanism, in Field R J, Burger M (Eds.), Oscillations and Travelling Waves in Chemical Systems, J. Wiley, New York, pp 605-613;

Blagojević S, Pejić N, Anić S, Kolar-Anić Lj (2000). Belousov Zhabitinsky Oscillatory Reaction. Kinetic of Malonic Acid Decomposition, J. Serb. Chem. Soc., 65, 709-713.

Blagojević SM, Anić SR, Čupić ŽD, Pejić ND and Kolar-Anić LjZ (2008). Malonic acid concentration as a control parameter in the kinetic analysis of the Belousov-Zhabotinsky reaction under batch conditions, Physical Chemistry Chemical Physics, 10, 6658-6664.

Blagojević SM, Anić SR, Čupić ŽD, Pejić ND, Kolar-Anić Lj Z (2009). Temperature Influence on the Malonic Acid Decomposition in the Belousov-Zhabotinsky Reaction, Russian J. Phys. Chem. A, 83, 1496-1501.

Blagojević SM, Anić SR, Čupić ŽD (2011). Influence of most important Radicals on the Numerically simulated Belousov-Zhabotinsky oscillatory reaction under batch conditions Russ. J. Phys. Chem. A, 85, 2274-2278. 
Blagojević SM, Anić SR, Čupić ŽD, Blagojević SN, Kolar-Anić LjZ (2013). Numerical Evidence of Complex Nonlinear Phenomena of the Belousov-Zhabotinsky Oscillatory Reaction under Batch Conditions, Russ. J. Phys. Chem. A, 87, 2140-2145.

Blagojević SN, Čupić Ž, Ivanović-Šašić A, Kolar-Anić Lj (2015). Mixed-mode Oscillations and Chaos in Return Maps of an Oscillatory Chemical Reaction, Russ. J. Phys. Chem. A, 13, 2349-2358.

Briggs TS, Rauscher WC (1973). An oscillating iodine clock, J. Chem. Educ., 50, 496.

Bubanja I N, Maćešić S, Ivanović-Šašić A, Čupić Ž, Anić S, Kolar-Anić Lj (2016), Intermittent chaos in the Bray-Liebhafsky Oscillator. Temperature Dependence, Physical Chemistry Chemical Physics, 18, 9770 - 9778.

Bray WC (1921). A Periodic Reaction in Homogeneous Solution and Its Relation to Catalysis, Journal of American Chemical Society, 43, 1262-1267.

Bray WC, Liebhafsky HA (1931). Reactin involving Hydrogen Peroxide , Iodine and Iodate Ion. I. Introduction, Journal of American Chemical Society, 53, 38-44.

Ćirić J, Anić S, Čupić Ž, Kolar-Anić Lj (2000). The Bray-Liebhafsky Oscillatory Reaction. Kinetic Investigations in Reduction and Oxidation Pathways based on Hydrogen Peroxide Concentration Monitoring, Science of Sintering, 32, 187-196.

Čupić Ž, Anić S, Terlecki-Baričević A, Kolar-Anić Lj (1995). The Bray-Liebhafsky Reaction. Influence of Some Polymers based on Poly (4-Vinylpyridine, React. Kinet. Catal. Lett., 54, 43-49.

Čupić Ž, Anić S, Mišljenović Đ (1996). The Bray-Liebhafsky Reaction. VII. Concentrations of the External Species $\mathrm{H}^{+}$and $\mathrm{IO}_{3}{ }^{-}$, J. Serb. Chem. Soc., 61, 893-902.

Čupić Ž, Marković V, Ivanović A, Kolar-Anić Lj (2011). Modeling of the Complex Nonlinear Processes: Determination of the Instability Region by the Stoichiometric Network Analysis. Mathematical Modelling, (Ed. Christopher R. Brennan) Nova Science Publishers Inc., New York, pp. 111-178.

Čupić Ž D, Ivanović-Šašić A, Anić S, Stanković B, Maksimović J, Kolar-Anić Lj, Schmitz G (2013). Tourbillion in the Phase Space of the Bray-Liebhafsky Nonlinear Oscillatory Reaction and Related Multiple-Time-Scale Model, MATCH Commun. Math. Comput. Chem., 69, 805-830.

Čupić ŽD, Kolar-Anić LjZ, Anić SR, Maćešić SR, Maksimović JP, Pavlović MS, Milenković MC, Bubanja INM, Greco E, Furrow SD, Cervellati R (2014). Regularity of Intermittent Bursts in Briggs-Rauscher Oscillating Systems with Phenol, Helvetica Chimica Acta, 97, 321-333.

Čupić Ž, Ivanović-Šašić A, Blagojević S, Blagojević S, Kolar-Anić Lj, Anić S (2016a). Return maps analysis of the highly nonlinear Bray-Liebhafsky reaction model, Reaction Kinetics, Mechanisms and Catalysis, 118, 27-38.

Čupić Ž, Marković V M, Maćešić S, Stanojević A, Damjanović S, Vukojević V, Kolar-Anić Lj (2016b). Dynamic transitions in a model of the hypothalamic-pituitary-adrenal (HPA) axis, Chaos: An Interdisciplinary Journal of Nonlinear Science, Chaos, 26, 03311.

Čupić Ž, Schmitz G, Kolar-Anić Lj (2016c). Stoichiometric Network Analysis as Mathematical Method for Examinations of Instability Region and Oscillatory Dynamics: Scientific Publications of the State university of Novi Pazar Ser. A: Appl. Math. Inform. and Mech., 8, 43-64.

Čupić Ž, Stanojević A, Marković V M, Kolar-Anić Lj, Terenius L, Vukojević V (in press). The HPA Axis and Ethanol - a Synthesis of Mathematical Modelling and Experimental Observations, Addiction Biology, doi: 10.1111/adb.12409.

Epstein IR, Pojman JA (1988). An Introduction to Nonlinear Chemical Dynamics, Oxford University Press, New York, USA.

Epstein IR, Pojman JA, Steinbock O (2006). Introduction: Self-organization in Nonequilibrium Chemical Systems, Chaos, 16, 037101-1-037101-7. 
Field RJ, Burger M (Eds.) (1985). Oscillation and Traveling Waves in Chemical Systems, J. Wiley, New York, USA.

Field RJ, Noyes R (1974). Oscillations in Chemical Systems. IV. Limit Cycle Behavior in a Model of a Real Chemical Reaction, J. Chem. Phys., 60, 1877-1884.

Gray P, Scott SK (1986). A New Model for Oscillator Behaviour in Close Systems: The Autocatalator, Berichte Bunsenges. Für Phys. Chem., 90, 985-996.

Gray P, Scott SK (1990). Chemical Oscillations and Instabilities, Clarendon Press, Oxford, United Kingdom

Ivanović AZ, Čupić ŽD, Janković MM, Kolar-Anić LjZ, Anić SR (2008). The Chaotic Sequences in the Bray-Liebhafsky reaction in an Open Reactor, Phys. Chem. Chem. Phys., 10, 5848-5858.

Ivanović AZ, Čupić ŽD, Kolar-Anić LjZ, Janković MM, Anić SR (2009). Large Deviation Spectra of Chaotic Time Series from Bray-Liebhafsky Reaction, R. J. Phys. Chem. A, 9, 1526-1530.

Ivanović AZ, Marković VM, Anić SR, Kolar-Anić LjZ, Čupić ŽD (2011). Structures of Chaos in Open Reaction Systems, Phys. Chem. Chem. Phys., 13, 20162-20171.

Jelić S, Čupić Ž, Kolar-Anić Lj (2008). Chapter XIII - Modelling of the HypothalamicPituitary-Adrenal System Activity Based on the Stoichiometric Analysis; in Eds. Elissa Romano and Sara de Luca, New Research on Neurosecretory Systems, Nova Science Publishers, Inc. Hauppauge NY pp. 225-245.

Jelić S, Čupić Ž, Kolar-Anić Lj, Vukojević V (2009). Predictive Modeling of the Hypothalamic-Pituitary-Adrenal (HPA) Function. Dynamic Systems Theory Approach by Stoichiometric Network Analysis and Quenching Small Amplitude Oscillations, International Journal of Nonlinear Sciences \& Numerical Simulation 10, 1451-1472.

Kolar-Anić Lj, Schmitz G (1992). Mechanism of the Bray-Liebhafsky Reaction: Effect of the Oxidation of Iodous Acid by Hydrogen Peroxide, J. Chem. Soc. Faraday Trans., 88, 23432349.

Kolar-Anić Lj, Mišljenović Đ, Anić S, Nicolis G (1995a). Influence of the Reduction of Iodate Ion by Hydrogen Peroxide on the Model of the Bray-Liebhafsky Reaction, React. Kinet. Catal. Lett., 54, 35-41.

Kolar-Anić Lj, Vukelić V, Mišljenović Đ, Anić S (1995b). On the Instability Domains of some Models for the Bray-Liebhafsky oscillatory Reaction, J. Serb. Chem. Soc., 60, 1005-1013.

Kolar-Anić Lj, Grozdić T, Vukojević V, Schmitz G, Anić S (2004a). Simulations of Complex Oscillations based on a Model of the Bray-Liebhafsky reaction. Selforganization in Nonequilibrium Systems, (Eds. Anić S, Čupić Ž and Kolar-Anić Lj), SPCS, Belgrade, Serbia, pp 115-118;

Kolar-Anić Lj, Vukojević V, Pejić N, Grozdić T, Anić S (2004b). Deterministic Chaos in Open Well-stirred Bray-Liebhafsky Reaction System, Experimental Chaos, (Eds. Boccaletti S, Gluckman B J, Kurths J, Pecora L, Meucci R and Yordanov Q, American Institute of Physics, New York, AIP Conference Proceedings, 742, 3-8.

Kolar-Anić Lj, Blagojević S, Pejić N, Begović N, Blagojević S, Anić S (2006). New Evidence of Transient Complex Oscillations in a Close, well-stirred Belousov-Zhabotinsky System, J. Serb. Chem. Soc., 71, 605-612.

Kolar-Anić Lj, Čupić Ž, Schmitz G, Anić S (2010). Improvement of the Stoichiometric Network Analysis for Determination of Instability Conditions of Complex Nonlinear Reaction Systems, Chemical Engineering Science, 65, 3718-3728.

Kolar-Anić Lj, Čupić Ž, Anić S, Pejić N, Vukojević V. (2017a). Complex Reaction Systems: Encyclopaedia of Physical Organic Chemistry, 6 Volume Set, Chapter 21.5. (Ed. Z. Wang) Wiley. (ISBN: 978-1-118-47045-9)

Kolar-Anić Lj, Čupić Ž, Anić S, Blagojević S, Vukojević V (2017b). Self-organizing Phenomena in Chemistry, Physical Chemistry and Biology: Encyclopaedia of Physical 
Organic Chemistry, 6 Volume Set, Chapter 21.6. (Ed. Z. Wang) Wiley. (ISBN: 978-1-11847045-9)

Kolar-Anić Lj, Čupić Ž, Anić S, Pejić N, Ivanović-Šašić A, Vukojević V (2017c). Methods for the Examination of Kinetics of Oscillatory Reactions: Encyclopaedia of Physical Organic Chemistry, 6 Volume Set, Chapter 21.6. (Ed. Z. Wang) Wiley. (ISBN: 978-1-118-47045-9)

Kolar-Anić Lj, Čupić Ž, Anić S, Blagojević S, Ivanović-Šašić A, Vukojević V (2017d). Models of Oscillatory Reactions: Encyclopaedia of Physical Organic Chemistry, 6 Volume Set, (Ed. Z. Wang) Wiley. (ISBN: 978-1-118-47045-9)

Lefever R, Nicolis G, Borckmans P (1988). The Brusselator: it does Oscillate all the Same, J. Chem. Soc. Faraday Trans. I, 84, 1013-1023.

Liebhafsky H (1931a). Reactiont involving Hydrogen Peroxide, Iodine and Iodate Ion. III. The Reduction of Iodate Ion by Hydrogen Peroxide, Journal of American Chemical Society, 53, 896-911.

Liebhafsky HA (1931b). Reactiont involving Hydrogen Peroxide, Iodine and Iodate Ion. III. The Reduction of Iodate Ion by Hydrogen Peroxide, IV. The Oxidation Iodine by Journal of American Chemical Society, 53, 2074-2090.

Liebhafsky HA (1932a). The Catalytic Decomposition of Hydrogen Peroxide by the IodineIodide Couple. II and III. Tha Rate of Oxidation in Netral, and in Acid, Solution of Hydrogen Peroxide by Iodine, Journal of American Chemical Society, 54, 3499-3503.

Liebhafsky HA (1932b). Tha Rate of Oxidation, in Acid Solution, of Hydrogen Peroxide by Iodine, Journal of American Chemical Society, 54, 3504-3508.

Liebhafsky HA, Mohammed A (1933). The Kinetic of the Reduction, in Acid Solution, Hydrogen Peroxide by Iodide Ion, Journal of American Chemical Society, 55, 3977-3086.

Liebhafsky HA (1934). The Catalytic Decomposition of Hydrogen Peroxide by the IodineIodide Couple. IV. The Approach to the Steady State, Journal of American Chemical Society, 56, 2369-2372.

Lotka AJ (1910). Contribution to the Theory of Periodic Reaction, Journal of Physical Chemistry, 14, 271-274.

Lotka AJ (1920a). Analytical Note on Certain Rhythmic Relations in Organic Systems, Proc. Natl. Acad. Sci. U.S.A., 6, 410-415.

Lotka AJ (1920b). Undamped Oscillations derived from the Low of Mass Action, J. Am. Chem. Soc., 42, 1595-1599.

Lotka AJ (1925). Elements of Physical Biology, Williams and Wilkins, Baltimore, USA.

Maćešić S, Čupić Ž, Anić S., Kolar-Anić Lj (2015a). Autocatalator as the Source of Instability in the Complex Non-linear Neuroendocrine Model, International Journal of Non-Linear Mechanics, 73, 25-30.

Maćešić SR, Čupić ŽD, Blagojević SM, Pejić ND, Anić SR, Kolar-Anić Lj Z (2015b). Current Rates and Reaction Rates in the Stoichiometric Network Analysis (SNA), Open Chemistry (fomerly Central European Journal of Chemistry),13, 591-599.

Maćešić S, Čupić Ž, Kolar-Anić Lj (2012). Model of the Nonlinear Reaction System With Autocatalysis and Autoinhibition: Stability of Dynamic States, Hemijska industrija, 66, 637-646.

Maćešić S, Čupić Ž, Kolar-Anić Lj (2016). Bifurcation Analysis of the Reduced Model of Bray-Liebhafsky Reaction, Reaction Kinetics, Mechanisms and Catalysis, 118, 39-55.

Maksimović JP, Čupić ŽD, Lončarević D, Pejić N, Vasiljević-Radović D, Anić S (2011). Kinetics of the Bray-Liebhafsky Oscillatory Reaction Perturbed by Polymer Supported Cobalt Catalyst, Science of Sintering, 43, 55-62.

Marković VM, Čupić Ž, Ivanović A,. Kolar-Anić Lj (2011a). The Stability of the Extended Model of Hypothalamic-Pituitary-Adrenal (HPA) Axis examined by Stoichiometric Network Analysis (SNA), Russ. J. Phys. Chem. A, 85, 2327-2335. 
Marković VM, Čupić Ž, Vukojević V, Kolar-Anić Lj (2011b). Predictive Modelling of the Hypothalamic-Pituitary-Adrenal (HPA) Axis Response to Acute and Chronic Stress, Endocrine Journal, 58 (2011) 889-904.

Marković VM, Čupić Ž, Maćešić S, Stanojević A, Vukojević V, Kolar-Anić Lj (2016). Modelling Cholesterol Effects on the Dynamics of the Hypothalamic-Pituitary-Adrenal (HPA) axis, Mathematical Medicine and Biology 33, 1-28.

Milenković MC, Stanisavljev DR (2012). Role of Free Radicals in Modeling the Iodide Peroxide Reaction Mechanism, The jounal of physical chemistry A, 116, 5541-5548.

Nicolis G (1995). Introduction to Nonlinear Science, Cambridge University Press, Cambridge, USA.

Nicolis G, Prigogine I (1977). Self-organization in Non-equilibrium Systems, J. Wiley, New York, USA.

Nicolis G, Prigogine I (1989). Exploring Complexity, Freeman, New York, USA.

Pejić N, Čupić Ž, Anić S, Vukojević V, Kolar-Anić Lj (2001). The Oscillatory Bray-Liebhafsky Reaction as a Matrix for Analyzing Enzyme and Polymeric Catalysts for Hydrogen Peroxide, Science of Sintering, 33, 107-155.

Pejić N, Anić S, Kuntić V, Vukojević V, Kolar-Anić Lj (2003). Kinetic Determination of Microquantities of Rutin by Perturbation of the Bray-Liebhafsky Oscillatory Reaction in an Open System, Micro Chemica Acta 143 261-267.

Pejić N, Blagojević S, Anić S, Vukojević V, Kolar-Anić Lj (2005). Microquantitative determination of hesperidin by pulse perturbation of the oscillatory reaction system, $J$. Anal. Bioanal. Chem., 381, 775-780.

Pejić N, Kolar-Anić Lj, Anić S, Stanisavljev D (2006). Determination of Paracetamol in Pure and Pharmaceutical Dosage Forms by Pulse Perturbation Technique, J. Pharmaceutical and Biomedical Analysis, 41, 610-615.

Pejić N, Blagojević SM, Anić S, Kolar-Anić Lj (2007a). Determination of Ascorbic Acide in Pharamaceutical Dosage Forms a Urine by means of an Oscillatory Reaction System using the Pulse Perturbation Thecnique, Anal. Bioanal. Chem., 389, 2009-2017.

Pejić ND, Blagojević SM, Anić SR, Vukojević VB, Mijatović MM, Ćirić JS, Marković ZS, Marković SD, Kolar-Anić LjZ (2007b). Kinetic Determination of Morphine by Means of Bray-Liebhafsky Oscillatory Reaction system using Analyte Pulse Perturbation Technique, Anal. Chim. Acta, 582, 367-374.

Pejić N, Blagojević S, Vukelić J, Kolar-Anić Lj, Anić S (2007c). Analyte Pulse Perturbation Technique for the Determination 6-monoacetylmorphyne in Seized Street Drug Sample, Bull. Chem. Soc. Jap., 80, 1942-1948.

Pejić N, Maksimović J, Ribič D, Kolar-Anić Lj (2009). Dynamic States of the Bray-Liebhafsky Reaction when Sulfuric Acid is the Control Parameter, Russian Journal of Physival Chemmistry A, 9, 1490-1495.

Pejić N, Vujković M, Maksimović J, Ivanović A, Anić S, Čupić Ž, Kolar-Anić Lj (2011). Dynamic Behavior of the Bray-Liebhafsky Oscillatory Reaction Controlled bz Sulfuric Acid and Temperature, Russian Journal of Physival Chemmistry A, 85, 2310-2316.

Pejić ND, Makismović JP, Blagojević SM, Anić SR, Čupić ŽD, Kolar-Anić, LjZ (2012). Kinetic Analytical Method for Determination of Uric Acid in Human Urine using Analyte Pulse Perturbation Technique, J. Braz. Chem. Soc., 23, 1450-1459.

Pejić ND, Sarap NB, Makismović JP, Anić SR, Kolar-Anić LjZ (2013). Pulse Perturbation Technique for Determination of Piroxicam in Pharmaceuticals using an Oscillatory Reaction System, Central European Journal of Chemistry, 11, 180-188.

Pejić N, Blagojević S, Sarap N, Maksimović J, Anić S, Čupić Ž, Kolar-Anić Lj (2014a). Perturbations of the Dushman reaction with Piroxicam: experimental and model calculations, Helvetica Chimica Acta, 97, 47-55. 
Pejić ND, Blagojević SM, Sarap NB, Makismović JP, Anić SR, Čupić ŽD, Kolar-Anić LjZ (2014b). Pertubation od the Duschman Reaction with Piroxicam: Experimantal and Model Calculations, Chelvetica Chimica Acta, 97, 47-55.

Pejić N, Kolar-Anić Lj, Maksimović J, Janković M, Ćukojević V, Anić S (2016). Dynamic Transitions in the Bray- Liebhafsky Oscillaing Reaction. Effect of Hydrogen Peroxide and Temperature on Bifurcation, Rect. Kinet. Mach. Cat., 118, 15-26.

Prigogine I (1977). Time, Structure and Fluctuations, Nobel Lecture in chemistry, Chemistry, 263-285.

Radenković M, Schmitz G, Kolar-Anić Lj (1997). Simulation of Iodine Oxidation by Hydrogen Peroxide in Acid Media, on the Basis of the Model of Bray-Liebhafsky Reaction, J. Serb. Chem. Soc., 62, 367-369.

Schmitz G (1987). Cinétique de la réaction de Bray, J. Chim. Phys., 84, 957-965.

Schmitz G, Kolar-Anić Lj, Anić S, Čupić Ž (2000). The Illustration of Multistability, J. Chem. Educ., 77, 1502-1505.

Schmitz G, Kolar-Anić Lj, Anić S, Grozdić T and Vukojević V (2006). Complex and Chaotic Oscillations in a Model for the Catalytic Hydrogen Peroxide Decomposition under Open Reactor Conditions, J. Phys. Chem. A, 110, 10361-10368.

Schmitz G, Kolar-Anić LjZ, Anić SR, Čupić ŽD (2008). Stoichiometric Network Analysis and Associated Dimensionless Kinetic Equations. Application to a Model of the BrayLiebhafsky Reaction, J. Phys. Chem. A, 112, 13452-13457

Scott SK (1987). Oscillations in Simple Models of Chemical Systems, Acc. Chem. Res., 20, 186-191.

Stanisavljev D, Vukojević V (1995). Thermochemical Effects Accompanying Oscillations in the Bray-Liebhafsky Reaction, J. Serb. Chem. Soc., 60, 1125-1334.

Stanisavljev D (1997). Consideration of the Thermodynamic Stability of Iodine Species in the Bray-Liebhafsky Reaction, Ber. Bunsenges. Phys. Chem. 101 1036-1039.

Stanisavljev D, Begović N, Žujović Z, Vučelić D, Bačić G (1998a). H NMR Monitoring of Water Behavior during the Bray-Liebhafsky Oscillatory Reaction J. Phys. Chem. A, 102, 6883-6886.

Stanisavljev D, Begović N, Vukojević V (1998b). Influence of Heavy Water on the BrayLiebhafsky Oscillating Reaction, J. Phys. Chem. A. 102, 6887-6891.

Stanisavljev D, Vukojević V (2002). Investigation of the Influence of Heavy Water Kinetic Pathways in the Bray-Liebhafsky Reaction, J. Phys. Chem. A, 106, 5618-5625.

Stanisavljev DR, Đorđević AR, Likar-Smiljanić VD (2004). Microwave Driven BrayLiebhafsky Oscillatory Reaction, Chem. Phys. Chem., 5, 140-144.

Stanisavljev D, Đorđević A, Likar-Smiljanić V (2005). Investigation of Microwave Effects on the Oscillatory Bray-Liebhafsky Reaction, Chem. Phys. Let., 412, 420-424.

Stanisavljev DR, Djordjević AR, Likar-Smiljanić VD (2006). Microwaves and Coherence in the Bray-Liebhafsky Oscillatory Reaction, Chemical Physics Letters, 423, 59-62.

Stanisavljev DR, Grozdić TD, Marceta Kaninski MP, Djordjević AR, Stojić DLj (2007). The Microwave Influence on the Electrolytic Decomposition of $\mathrm{KOH}$ Water Solution, Electrochemistry Communications, 9, 901-904.

Stanisavljev DR, Dramicanin MD (2007). Excessive Excitation of Hydrogen Peroxide during Oscillatory Chemical Evolution, Journal of Physical Chemistry A, 111, 7703-7706.

Stanisavljev DR, Milenković MC, Mojović MD, Popović-Bijelić AD (2011). Oxygen Centered Radicals in Iodine Chemical Oscillators. J. Phys. Chem. A, 115, 7955-7958.

Stanisavljev DR, Velikić Z, Veselinović DS, Jacić NV, Milenković MC (2014). BrayLiebhafsky Oscillatory Reaction in the Radiofrequency Electromagnetic Field, Chemical Physics, 441, 1-4

Stanković B, Čupić Ž, Pejić N, Kolar-Anić Lj (2013). Numerical Study on Bray-Liebhafsky Oscillatory Reaction: Bifurcations, Journal of Applied Nonlinear Dynamics 2, 285-301. 
Stanković B, Čupić Ž, Maćešić S, Pejić N, Kolar-Anić Lj (2016). Complex Bifurcations in the Oscillatory Reaction Model, Chaos, Solitons and Fractals: the interdisciplinary journal of Nonlinear Science, 87, 84-91.

Stávek J, Šípek M, Šesták J (2002). The application of the principle of least action to some selforganized chemical reactions, Thermochimica Acta, 388 441-450.

Terlecki-Baričević A, Čupić Ž, Anić S, Kolar-Anić Lj (1995). Mitrovski, S, Ivanović, S, Polyvinylpiridine supported Iron(III) Catalyst for Hydrogen Peroxide Decomposition, $J$. Serb. Chem. Soc., 60, 969-979.

Voltera V (1926). Fluctuations in the Abundance of a Species considered Mathematically, Nature, 118, 558-560.

Vukojević V, Pejić N, Stanisavljev D, Anić S, Kolar-Anić Lj (1999). Determination of $\mathrm{Cl}^{-}, \mathrm{Br}^{-}$, $\mathrm{I}^{-}, \mathrm{Mn}^{2+}$, Malonic acid and Quercentin by Perturbation of Non-equlibrium Stationary State in the Bray-Liebhafsky Reaction, The Analyst, 124, 147-152

Vukojević V, Anić S, Kolar-Anić Lj (2000), Investigation of Dynamic Behaviour of the BrayLiebhafsky Reaction in the CSTR. Determination of Bifurcation Points, J. Phys. Chem. A, 104, 10731-10739.

Vukojević V, Pejić, N, Stanisavljev D, Anić S, Kolar-Anić Lj (2001). Micro-quantitative Determination of Quercentin by Perturbation of Non-equilibrium Stationary State in the Bray-Liebhafsky Reaction, Die Pharmazie, 56, 897-898.

Vukojević V, Anić S, Kolar-Anić Lj (2002). Investigation of Dynamic Behaviour of the BrayLiebhafsky Reaction in the CSTR. Properties of the System Examined by Pulsed Perturbation with I', Phys. Chem. Chem. Phys. 4, 1276-1283.

Winfree AT (1984). The Prehistory of the Belousov-Zhabotinsky Oscillator, Journal of Chemical Education, 61, 661-663.

Zhabotinskii AM (1964). Periodical Oxidation of Malonic Acid in Solution, Biofizika, 9, 306311.

Zhabotinskii AM (1991). A History of Chemical Oscillations and Waves, Chaos, 1, 379-386. 